\title{
Effects of Glutamine on Digestive Function and Redox Regulation in the Intestines of Broiler Chickens Challenged with Salmonella Enteritidis
}

http://dx.doi.org/10.1590/1806-9061-2019-1123

\section{-Author(s)}

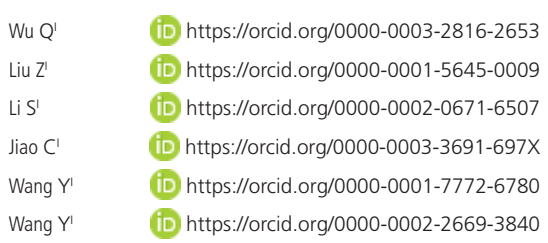

College of Animal Science and Technology, Henan University of Science and Technology, Luoyang 471003, Henan, PR China.

\section{-Mail Address}

Corresponding author e-mail address Wu Qiujue

College of Animal Science and Technology, Henan University of Science and

Technology, Luoyang 471003, Henan, PR China.

Phone: +860379 64282341

Email: wuqiujue@163.com

\section{EKeywords}

Glutamine, average body weight, antioxidant function, Salmonella Enteritidis, broiler.

\section{ABSTRACT}

The aim was to investigate the effect of glutamine (Gln) on broilers challenged with Salmonella Enteritidis. 240 1-day-old birds were divided into four groups in a completely randomized design, each of which included 6 replicates with 10 birds per replicate. Group I served as the unchallenged, untreated control (CON). All birds in groups II (SCC) - IV were challenged with $2.0 \times 10^{4} \mathrm{CFU} / \mathrm{mL}$ of S. Enteritidis. Birds in group III and IV were treated with $0.5 \%(G \ln 1)$ and $1.0 \%$ (Gln 2), respectively, of Gln. The results indicated that S. Enteritidis infection led to a decrease in the average body weight at $d 7,14$, and $21(p<0.05)$. Chickens fed the Gln showed improved average body weights in comparison with the SCC group $(p<0.05)$. At $d 4,7,14$, and 21, the Gln groups increased digestive enzyme (trypsin, lipase and amylase (except the amylase activity of jejunum at $d 14$ and $d 21$ )) activities in the intestine $(p<0.05)$, superoxide dismutase (SOD) (at $d$ 14 jejunum; except at $d 4$, ileum) and catalase (CAT) (at d 4, and d 21, jejunum; $d 4$, ileum) activity in the serum (except at d 14) and intestinal mucosa $(p<0.05)$, and the mRNA expression of SOD, CAT and nuclear respiratory factor 2 (Nrf2) of the intestinal mucosa compared with the SCC group $(p<0.05)$. These results suggest that $\mathrm{Gln}$ as a feed additive could be effective for reducing the detrimental effects of $S$. Enteritidis infection of broilers.

\section{INTRODUCTION}

Salmonella Enteritidis is capable of colonizing the gut effectively (Eliana et al., 2012), and it can produce systemic or septicaemic disease in young chickens. Salmonella attaches to the intestinal cells and epithelium, causing alteration of the redox status of the jejunal mucosa and superoxide dismutase (SOD) and glutathione reductase activity in the infected hosts (Popkova et al., 1984; Alaeldein et al., 2017). Moreover, evidence from animal study has shown that $S$. Enteritidis infection can also adhere to glycoproteins of the intestinal epithelium and induce the activation of immune cells, lead to injury of the colonic mucous epithelium, thereby causing diffuse extraintestinal infections and an inflammatory response with diarrhea (Wu et al., 2018). The pathogenesis of this condition is complex and is strongly implicated in compromised growth and mortality of the birds (Taunay et al., 1996). Therefore, control programs for intestinal colonization caused by $S$. Enteritidis are essential to protect the health of the birds and ensure the safety of consumers. Glutamine ( $\mathrm{Gln}$ ) is considered as a conditionally essential amino acid (Newsholme, 2001) and is a critical fuel source and a potent mitogen for intestinal enterocytes (Jacobs et al., 1988). Previous studies have shown that Gln treatment can improve the average body weight, feed conversion ratio, abdominal morphological structures, intestinal cell metabolism, and the activity of digestive enzyme as a 
result of reducing the $\mathrm{pH}$ in the alimentary tract (Lin \& Zhou, 2006; Wu et al., 2019). Recent work also demonstrated that pretreatment with GIn attenuated cytokine release and improved the activity of the gut antioxidant defense system, which involves protecting the epithelial barrier function, in an animal model of endotoxemia (Kazantzidou et al., 2010; Geng, 2011; Li et al., 2014). However, little research has been conducted on the regulatory mechanism of the internal redox state on GIn in Salmonella-challenged birds. Hence, the purpose of this research was to find the possible antioxidant properties of GIn on serum and intestinal tissues to reduce the colonization of $S$. Enteritidis in the intestine and the impact of Gln on the digestive function after the challenge in broiler chicks.

\section{MATERIALS AND METHODS}

\section{S. Enteritidis}

S. Enteritidis serotype was provided by China Veterinary Culture Collection Center (CVCC 3377, Beijing, China). S. Enteritidis was cultured in Brilliant Green Agar at $37^{\circ} \mathrm{C}$ for $24 \mathrm{~h}$, washed, and then diluted to $2.0 \times 10^{4} \mathrm{CFU} / \mathrm{mL}$ in sterile normal saline. Colony counts by plating confirmed the viable cells.

\section{Broiler, management and experimental diets}

Two hundred and forty 1-day-old commercial Arbor Acres broilers (mixed male and female), were obtained from a local hatchery in Luoyang, China. The birds were weighed and placed in two separate 3-tier battery cages in an environmentally controlled room; the broilers were exposed to ambient temperatures that gently decreased from $34^{\circ} \mathrm{C}$ to $22 \pm 1^{\circ} \mathrm{C}$ until $21 \mathrm{~d}$ of age. Plastic separators were used to prevent horizontal contamination between the cages. The experimental chickens were provided twenty-three hours of light at days 1 to 7 , and $18 \mathrm{~h}$ light at days 8 to 21 . The birds were fed mash diet formulated according to the NRC (1994) recommendations to meet or exceed the nutrient and energy requirements of broilers (Table 1) and allowed access to feed and water ad libitum. Gln (pharmaceutical grad: 99\% purity, Henan Honda Biological Medicine Co., Ltd., China) was supplemented and thoroughly mixed into the basal feed. Fresh feed was prepared and stored in sealed bottles at room temperature. The experiment was done under the supervision of the Institutional Animal Care and Use Committee of Henan University of Science and Technology.
Table 1 - Ingredients and nutrient level of the experimental $\operatorname{diet}(\%)$.

\begin{tabular}{lc}
\hline Feed Ingredients (\%) & $1-21 \mathrm{~d}$ \\
\hline Corn silage & 54.6 \\
Corn gluten meal & 35.5 \\
Soybean oil & 3.5 \\
Limestone & 1.2 \\
Dicalcium phosphate & 1.5 \\
Salt & 3.0 \\
50\% Choline chloride & 0.14 \\
Premix & 0.24 \\
\hline L-Lysine & 0.12 \\
DL-Methionine & 0.2 \\
Total & 100 \\
Calculated nutrients levels (\%) & \\
Apparent metabolisable energy (AME) (MJ/kg ) & 12.55 \\
Crude protein (CP) & 21.00 \\
Ca & 0.90 \\
Available Phosphorus & 0.45 \\
Lys & 1.15 \\
Met+cys & 0.80 \\
\hline
\end{tabular}

Note: 'Each kg of premix contained: Fe (from ferrous sulfate), $80 \mathrm{mg}$; $\mathrm{Cu}$ (from copper sulfate), 8 mg; Mn (from manganese sulfate), $100 \mathrm{mg}$ Z Zn (Bacitracin Zn), 65 mg; iodine (from calcium iodate), $0.35 \mathrm{mg}$; Se (from sodium selenite), $0.15 \mathrm{mg}$. Vitamin A (transretinyl acetate), 12,500 IU; Vitamin $\mathrm{D}_{3}$ (cholecalciferol), 2,500 IU; Vitamin E, $18.5 \mathrm{mg}$; Vitamin $\mathrm{K}_{3}, 2.65 \mathrm{mg}$; thiamine $2.2 \mathrm{mg}$; riboflavin, $8 \mathrm{mg}$; nicotinamide, 40 $\mathrm{mg}$; pyridoxine $\mathrm{HCl}, 4 \mathrm{mg}$; biotin, $0.04 \mathrm{mg}$; folic acid, $1 \mathrm{mg}$; vitamin $\mathrm{B}_{12}$ (cobalamine), $0.013 \mathrm{mg}$.

\section{Experimental protocol}

Broilers were used in a completely randomized design with four treatment groups, each of which included six replicates with ten birds (half male and half female) per replicate.

Group I served as the unchallenged, untreated control (the negative control group, CON). At three days of age, all the other birds in group II $(S C C=S$. Enteritidis infect control group), III (GIn1=S. Enteritidis infect control group received the basal diet plus $0.5 \%$ $\mathrm{G} \ln )$, and IV ( $\mathrm{G} \ln 2=S$. Enteritidis infect control group received the basal diet plus $1.0 \% \mathrm{Gln}$ ) received by oral gavage $2.0 \times 10^{4} \mathrm{CFU}$ each $(0.5 \mathrm{~mL})$ of $\mathrm{S}$. Enteritidis suspension. Each chick in the unchallenged group received an equivalent amount of sterile normal saline. The trial lasted $21 \mathrm{~d}$.

\section{Growth performance}

At days $1,3,4,7,14$, and 21 , the birds were weighed individually after an overnight fast, and then the data was used to calculate the average body weights on days $3,4,7,14$, and 21 .

\section{Sample collection and procedures}

Before sampling, broiler chickens starved for 12 h. On d 1, 7, 14 and 21, six chicks per cage were 
randomly selected, and immediately euthanized with cervical dislocation. $5.0 \mathrm{~mL}$ blood samples were taken from the caudal veins, and samples were centrifuged for $15 \mathrm{~min}$ at $1,800 \times \mathrm{g}$ for the collection of the serum.

During necropsy the jejunum and ileum were dissected free of the mesentery. Approximately 2 and $10 \mathrm{~cm}$ long segment of the jejunum and the ileum were resected at mid-jejunum and mid-ileum, gut contents from the jejunum and the ileum were collected into the plastic collection tubes and stored at $-80{ }^{\circ} \mathrm{C}$ to determine digestive enzyme activity. Then, each residual intestine segment was opened longitudinally, cleaned with a physiological saline solution, and the mucosa samples were gently scraped with a glass microscope slide, and separated into two subsamples. One mucosa subsample was stored quickly at $-80^{\circ} \mathrm{C}$ to assess RNA quality. The other mucosa scraping was subsampled, then placed on ice until they were centrifuged for $10 \mathrm{~min}$ at 1,200 to $1,500 \times \mathrm{g}$, the suspension was gathered, and then stored immediately at $-80^{\circ} \mathrm{C}$ for future antioxidant enzyme assays.

\section{Biochemical assay determination of serum and intestine mucosa parameters}

According to the instructions of the manufacturer, the digestive enzymes included amylase (catalog No. C016-1), trypsin (catalog No. A054), and lipase (catalog No. A080-2) detected by the detection kits (Nanjing Jiancheng Bioengineering Institute, Nanjing, China). Total protein concentration was assayed according to the method of Bradford (1976). The detection kits from the same source were used to detect the concentration of Catalase (CAT, catalog No. A007-1), malondialdehyde (MDA, catalog No. A003-
1), SOD (catalog No. A001-1) and protein (catalog No. A045-3).

\section{RNA Isolation and real-time quantitative PCR}

Total RNA of the intestinal mucosa samples $(2 \mu \mathrm{g})$ was isolated by TRIzol reagent (Invitrogen Trading (Shanghai) Co., Ltd., China) and ground using a homogenizer, according to the instructions of the manufacturer. The RNA pellets were dried at $55^{\circ} \mathrm{C}$ for 10 min and resuspended in buffer with ten $\mathrm{mM}$ tris hydrochloride and one mM EDTA at a pH of 8.0. The RNA integrity was electrophoresed by $1 \%$ agaroseformaldehyde gel. The amplified RNA quantity was detected using a spectrophotometer (Gene Quant 1300/100, General Electric Company, USA). Then, $1 \mu \mathrm{g}$ RNA was immediately reverse transcribed into cDNA by using reverse transcription kits. Subsequently, labeled cRNAs were disrupted, incubated, diluted, and assembled RNA microarray. The PCR was performed in duplicate on each sample. The specific primers for nuclear respiratory factor 2 (Nrf2), SOD, and CAT are summarized in Table 2. According to the instructions of the manufacturer, qRT-PCR reactions were run with the SYBR ${ }^{\circledR}$ Green RT-PCR Kit. The following PCR amplification parameters were used, namely, 2 min at $50^{\circ} \mathrm{C}$; $10 \mathrm{~min}$ at $95^{\circ} \mathrm{C}$; and cycle numbers were 40 at $95^{\circ} \mathrm{C}$ for $10 \mathrm{~s}, 20 \mathrm{~s}$ at $60^{\circ} \mathrm{C}, 65^{\circ} \mathrm{C}$ for $1 \mathrm{~min}$. The relative fold-change from different parts of small intestine was calculated by the $2^{-\Delta \Delta c t}$ method, which accounts for gene-specific efficiencies and was normalized to the mean expression of the abovementioned index (Livak \& Schmittgen, 2001; Liu et al., 2010).

Table 2 - Specific Primer sequences for target and $\beta$-actin genes.

\begin{tabular}{|c|c|c|c|}
\hline GeneName & Gene NO. & Primer Sequence & Fragment Size \\
\hline \multirow{2}{*}{ SOD } & \multirow{2}{*}{ NM_205064.1 } & 5'-TTGTCTGATGGAGATCATGGCTTC-3' & \multirow{2}{*}{98 bp } \\
\hline & & 5'-TGCTTGCCTTCAGGATTAAAGTGA-3' & \\
\hline \multirow{2}{*}{ CAT } & \multirow{2}{*}{ NM_001031215.1 } & 5'-GTTGGCGGTAGGTCTGGTCT-3' & \multirow{2}{*}{$182 \mathrm{bp}$} \\
\hline & & 5'-GTGGTCAAGGCATCTGGCTTCTG-3' & \\
\hline \multirow{2}{*}{ Nrf2 } & \multirow{2}{*}{ NM_205117.1 } & 5'-ATCACCTCTTCTGCACCGAA-3' & \multirow{2}{*}{$258 \mathrm{bp}$} \\
\hline & & 5'-GCTTTCTCCCGCTCTTTCTG-3' & \\
\hline \multirow{2}{*}{$\beta$-actin } & \multirow{2}{*}{ NM_2055518.1 } & 5'-AGCGAACGCCCCCAAAGTTCT-3' & \multirow{2}{*}{$139 \mathrm{bp}$} \\
\hline & & 5'-AGCTGGGCTGTTGCCTTCACA-3' & \\
\hline
\end{tabular}

\section{Statistical methods}

All analyses were performed using statistical software SPSS version 21.0 (SPSS Inc., Chicago, IL, USA, 2012), and differences between means were examined using the Duncan multiple range test of SPSS. All results were expressed as the mean with the standard deviation. Statistically significance was declared for $p<0.05$.

\section{RESULTS}

\section{Average body weight and mortality}

There were no significant differences among the CON, SCC, and Gln groups on days 3 and 4 ( $p>0.05$ ) (Table 3). However, the present study indicated the lowest average body weight gain in $S$. Enteritidis infected birds (group SCC) compared with control 
Table 3 - Effect of dietary Gln on the average body weight (g) of broilers infected with S. Enteritidis.

\begin{tabular}{|c|c|c|c|c|}
\hline \multirow{2}{*}{ Items } & \multicolumn{4}{|c|}{ Diet Treatments ${ }^{1}$} \\
\hline & $\mathrm{CON}$ & SCC & $\mathrm{G} \ln 1$ & $\mathrm{G} \ln 2$ \\
\hline $3 d$ & $83.59 \pm 1.10$ & $83.60 \pm 1.27$ & $84.76 \pm 1.08$ & $84.95 \pm 1.21$ \\
\hline $4 d$ & $102.28 \pm 2.94$ & $100.24 \pm 3.08$ & $101.06 \pm 1.97$ & $102.09 \pm 3.14$ \\
\hline $7 d$ & $190.63 \pm 6.00^{b}$ & $155.24 \pm 5.21^{\mathrm{a}}$ & $181.38 \pm 4.62^{b}$ & \\
\hline $14 \mathrm{~d}$ & $488.55 \pm 10$ & $435.07 \pm 9.38^{a}$ & $479.09 \pm$ & $4^{b}$ \\
\hline $21 \mathrm{~d}$ & $5.50 \pm 18$ & $9.67 \pm 12.24^{\mathrm{a}}$ & $920.23 \pm 14.39^{b}$ & $947.68 \pm 16.20^{b}$ \\
\hline Mortality rates (\%) & 0 & 3.33 & 1.67 & 0 \\
\hline \multicolumn{5}{|c|}{$\begin{array}{l}{ }^{1} \mathrm{CON}=\text { noninfect control group, } S C \mathrm{CC}=S \text {. Enteritidis infect control group received the basal diet, } \mathrm{Gln} 1=S \text {. Enteritidis infect control group received the basal diet plus } 0.5 \% \mathrm{Gln} \text {; } \\
\mathrm{Gln} 2=\mathrm{S} \text {. Enteritidis infect control group received the basal diet plus } 1.0 \% \text { Gln. } \\
2, a, \mathrm{~b} \text { VValues within the same row that do not share a common superscript are significantly different at } p<0.05 ; n=8 .\end{array}$} \\
\hline \multicolumn{5}{|c|}{ 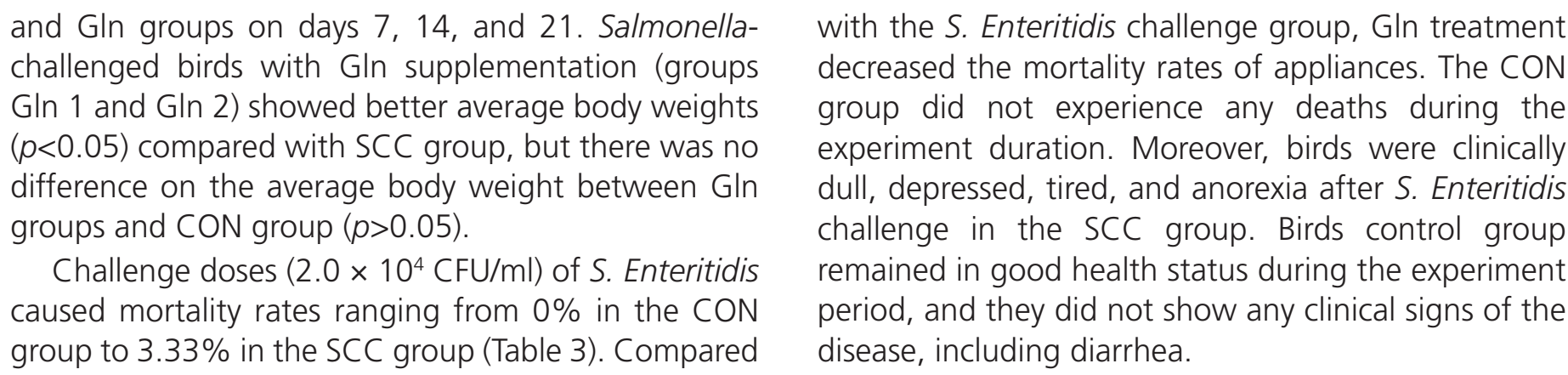 } \\
\hline
\end{tabular}

Table 4 - Effect of dietary GIn on the digestive enzyme activitys of broilers infected with S. Enteritidis.

\begin{tabular}{|c|c|c|c|c|c|}
\hline \multirow{2}{*}{ Items } & & \multicolumn{4}{|c|}{ Diet Treatments $^{1}$} \\
\hline & & $\mathrm{CON}$ & SCC & $\mathrm{Gln} 1$ & $G \ln 2$ \\
\hline \multicolumn{6}{|l|}{$4 d$} \\
\hline \multirow{3}{*}{ Jejunum } & Trypsin (U/g) & $1165.53 \pm 111.27^{b}$ & $907.52 \pm 92.24^{\mathrm{a}}$ & $1095.65 \pm 102.84^{b}$ & $1170.14 \pm 101.29^{b}$ \\
\hline & Lipase (U/mg) & $148.27 \pm 10.45^{b}$ & $116.37 \pm 9.46^{a}$ & $139.34 \pm 6.37^{b}$ & $143.62 \pm 5.97^{b}$ \\
\hline & Amylase (U/mg) & $57.12 \pm 1.62^{b}$ & $50.76 \pm 2.04^{a}$ & $56.85 \pm 2.83^{b}$ & $57.86 \pm 1.23^{b}$ \\
\hline \multirow{3}{*}{ Ileum } & Trypsin (U/g) & $1652.16 \pm 111.13^{b}$ & $1108.75 \pm 109.34^{a}$ & $1588.60 \pm 100.72^{b}$ & $1619.76 \pm 110.07^{b}$ \\
\hline & Lipase (U/mg) & $100.10 \pm 10.01^{b}$ & $54.32 \pm 5.17^{a}$ & $94.18 \pm 6.31^{b}$ & $103.41 \pm 9.17^{b}$ \\
\hline & Amylase (U/mg) & $54.76 \pm 4.38^{b}$ & $25.24 \pm 3.21^{\mathrm{a}}$ & $51.87 \pm 1.40^{\mathrm{b}}$ & $53.45 \pm 5.24^{b}$ \\
\hline \multicolumn{6}{|l|}{$7 d$} \\
\hline \multirow{3}{*}{ Jejunum } & Trypsin (U/g) & $1079.65 \pm 102.32^{b}$ & $804.75 \pm 82.04^{a}$ & $980.19 \pm 83.82^{b}$ & $1076.90 \pm 91.09^{b}$ \\
\hline & Lipase (U/mg) & $136.54 \pm 22.23^{b}$ & $106.56 \pm 20.13^{a}$ & $129.65 \pm 16.71^{b}$ & $138.80 \pm 24.28^{b}$ \\
\hline & Amylase (U/mg) & $48.96 \pm 3.69^{b}$ & $43.19 \pm 2.67^{a}$ & $47.61 \pm 5.07^{b}$ & $49.18 \pm 3.37^{b}$ \\
\hline \multirow{3}{*}{ Ileum } & Trypsin (U/g) & $1720.46 \pm 102.31^{b}$ & $1327.43 \pm 99.67^{a}$ & $1608.69 \pm 100.04^{b}$ & $1719.94 \pm 110.20^{b}$ \\
\hline & Lipase (U/mg) & $111.09 \pm 12.86^{\mathrm{b}}$ & $60.46 \pm 10.21^{a}$ & $99.86 \pm 9.84^{b}$ & $108.04 \pm 10.04^{b}$ \\
\hline & Amylase (U/mg) & $46.89 \pm 6.76^{b}$ & $21.37 \pm 6.20^{\mathrm{a}}$ & $42.19 \pm 2.43^{b}$ & $47.31 \pm 3.01^{\mathrm{b}}$ \\
\hline \multicolumn{6}{|l|}{$14 \mathrm{~d}$} \\
\hline \multirow{3}{*}{ Jejunum } & Trypsin (U/g) & $898.45 \pm 45.31^{b}$ & $614.24 \pm 51.76^{a}$ & $880.13 \pm 30.27^{b}$ & $894.46 \pm 23.27^{b}$ \\
\hline & Lipase (U/mg) & $96.48 \pm 16.34^{b}$ & $63.69 \pm 11.20^{\mathrm{a}}$ & $90.69 \pm 13.45$ & $95.41 \pm 9.19$ \\
\hline & Amylase (U/mg) & $39.10 \pm 2.65$ & $36.96 \pm 2.99$ & $38.56 \pm 6.41$ & $40.27 \pm 4.65$ \\
\hline \multirow{3}{*}{ Ileum } & Trypsin (U/g) & $1808.93 \pm 52.89^{b}$ & $1235.67 \pm 110.24^{a}$ & $1761.30 \pm 123.45^{b}$ & $1800.62 \pm 98.67^{b}$ \\
\hline & Lipase (U/mg) & $130.89 \pm 13.59^{b}$ & $100.02 \pm 5.67^{a}$ & $120.17 \pm 4.63^{b}$ & $129.84 \pm 3.48^{b}$ \\
\hline & Amylase (U/mg) & $28.56 \pm 5.43^{\mathrm{b}}$ & $14.53 \pm 3.07^{b}$ & $26.74 \pm 4.69^{b}$ & $30.01 \pm 3.76^{b}$ \\
\hline \multicolumn{6}{|l|}{$21 \mathrm{~d}$} \\
\hline \multirow{3}{*}{ Jejunum } & Trypsin (U/g) & $826.01 \pm 32.14^{b}$ & $536.84 \pm 21.18^{a}$ & $817.81 \pm 11.76^{b}$ & $828.34 \pm 22.32^{b}$ \\
\hline & Lipase (U/mg) & $69.97 \pm 7.15^{b}$ & $44.38 \pm 5.95^{\mathrm{a}}$ & $61.67 \pm 6.46^{b}$ & $69.43 \pm 3.39^{b}$ \\
\hline & Amylase (U/mg) & $10.73 \pm 5.98$ & $8.59 \pm 8.67$ & $9.76 \pm 9.75$ & $10.43 \pm 7.31$ \\
\hline \multirow{3}{*}{ Ileum } & Trypsin (U/g) & $2000.53 \pm 120.43^{b}$ & $1567.38 \pm 139.47^{a}$ & $1896.41 \pm 140.08^{b}$ & $1997.86 \pm 101.72^{b}$ \\
\hline & Lipase (U/mg) & $155.86 \pm 16.30^{\mathrm{b}}$ & $107.85 \pm 18.97^{a}$ & $142.30 \pm 10.34^{b}$ & $154.97 \pm 11.27^{b}$ \\
\hline & Amylase (U/mg) & $15.76 \pm 4.21^{\mathrm{b}}$ & $7.68 \pm 3.02^{\mathrm{a}}$ & $13.47 \pm 5.00^{\mathrm{b}}$ & $14.89 \pm 2.68^{b}$ \\
\hline
\end{tabular}

${ }^{1} \mathrm{CON}=$ noninfect control group, $\mathrm{SCC}=\mathrm{S}$. Enteritidis infect control group received the basal diet, $\mathrm{Gln} 1=\mathrm{S}$. Enteritidis infect control group received the basal diet plus $0.5 \% \mathrm{Gln}$; Gln $2=$ S. Enteritidis infect control group received the basal diet plus $1.0 \% \mathrm{Gln}$.

$2, a, b$ Values within the same row that do not share a common superscript are significantly different at $p<0.05 ; n=8$. 


\section{Activities of digestive enzymes}

At $d 4,7,14$, and 21, S. Enteritidis infection significantly decreased the trypsin, lipase, and amylase (jejunum excluded at $d 14$ and $d 21$ ) activity in the jejunum and the ileum as compared with the control $(p<0.05)$ (Table 4). The $G \ln 1$ and $G \ln 2$ groups showed significantly increased trypsin, lipase, and amylase activity of the jejunum and ileum compared with the S. Enteritidis infection group $(p<0.05)$. However, there were no differences on the trypsin, lipase, and amylase activities between the CON group and the SCC group (p>0.05).

\section{Antioxidant indices}

At $d 4,7$, and 21, contrasting with the control group, S. Enteritidis infection decreased the serum CAT and SOD concentration of broilers $(p<0.05)$ (Table 5). However, Gln 1 and Gln 2 groups showed increased serum CAT and SOD concentration as compared with

Table 5 - Effect of dietary Gln on the serum and mucosa antioxidation function of broilers infected with S. Enteritidis.

\begin{tabular}{|c|c|c|c|c|c|}
\hline \multirow{2}{*}{ Items } & & \multicolumn{4}{|c|}{ Diet Treatments ${ }^{1}$} \\
\hline & & $\mathrm{CON}$ & SCC & $\mathrm{G} \ln 1$ & $\mathrm{Gln} 2$ \\
\hline \multicolumn{6}{|l|}{$4 d$} \\
\hline \multirow{3}{*}{ Serum } & CAT (U/mL) & $8.76 \pm 0.34^{b}$ & $3.80 \pm 1.02^{\mathrm{a}}$ & $8.66 \pm 0.31^{b}$ & $8.80 \pm 0.50^{b}$ \\
\hline & $\mathrm{SOD}(\mathrm{U} / \mathrm{mL})$ & $100.27 \pm 5.86^{b}$ & $82.58 \pm 4.29^{a}$ & $106.46 \pm 6.21^{b}$ & $109.78 \pm 3.37^{b}$ \\
\hline & MDA (nmol/mL) & $2.31 \pm 0.29$ & $2.85 \pm 0.50$ & $2.29 \pm 0.32$ & $2.08 \pm 0.43$ \\
\hline \multirow{3}{*}{ Jejunum } & CAT (U/mg prot) & $14.38 \pm 1.23^{b}$ & $4.27 \pm 0.86^{a}$ & $13.77 \pm 1.05^{b}$ & $14.17 \pm 0.82^{b}$ \\
\hline & SOD (U/mg prot) & $225.85 \pm 20.15$ & $160.38 \pm 12.76$ & $199.98 \pm 10.00$ & $210.73 \pm 13.84$ \\
\hline & MDA (nmol/ mg prot) & $0.12 \pm 0.01^{a}$ & $0.26 \pm 0.07 b$ & $0.08 \pm 0.02^{\mathrm{a}}$ & $0.11 \pm 0.01^{\mathrm{a}}$ \\
\hline \multirow{3}{*}{ lleum } & CAT (U/mg prot) & $10.63 \pm 1.79^{b}$ & $4.98 \pm 1.14^{a}$ & $9.94 \pm 1.59^{b}$ & $10.77 \pm 1.83^{a}$ \\
\hline & SOD (U/mg prot) & $145.17 \pm 13.02$ & $95.71 \pm 20.13$ & $148.61 \pm 21.60$ & $152.27 \pm 21.20$ \\
\hline & $\mathrm{MDA}$ (nmol/ mg prot) & $0.47 \pm 0.05 a$ & $0.72 \pm 0.01^{b}$ & $0.50 \pm 0.07^{a}$ & $0.45 \pm 0.02^{\mathrm{a}}$ \\
\hline \multicolumn{6}{|l|}{$7 d$} \\
\hline \multirow{3}{*}{ Serum } & CAT (U/mL) & $10.52 \pm 1.28^{b}$ & $4.05 \pm 1.15^{\mathrm{a}}$ & $9.89 \pm 1.00^{b}$ & $10.37 \pm 0.56^{b}$ \\
\hline & $\mathrm{SOD}(\mathrm{U} / \mathrm{mL})$ & $108.89 \pm 4.32^{b}$ & $30.27 \pm 3.01^{\mathrm{a}}$ & $106.64 \pm 3.81^{b}$ & $109.94 \pm 5.58^{b}$ \\
\hline & $\mathrm{MDA}(\mathrm{nmol} / \mathrm{mL})$ & $3.18 \pm 0.43^{\mathrm{a}}$ & $4.86 \pm 0.32^{b}$ & $3.22 \pm 0.26^{a}$ & $3.11 \pm 0.19$ \\
\hline \multirow{3}{*}{ Jejunum } & CAT (U/mg prot) & $4.02 \pm 1.62$ & $2.09 \pm 0.86$ & $3.72 \pm 1.01$ & $3.98 \pm 1.90$ \\
\hline & SOD (U/mg prot) & $290.75 \pm 20.19$ & $203.08 \pm 11.32$ & $246.31 \pm 20.93$ & $289.72 \pm 24.37$ \\
\hline & MDA (nmol/ mg prot) & $0.20 \pm 0.01^{\mathrm{a}}$ & $0.38 \pm 0.05^{b}$ & $0.25 \pm 0.02^{\mathrm{a}}$ & $0.19 \pm 0.03^{a}$ \\
\hline \multirow{3}{*}{ Ileum } & CAT (U/mg prot) & $2.35 \pm 0.17$ & $1.99 \pm 0.20$ & $2.24 \pm 0.42$ & $2.57 \pm 0.75$ \\
\hline & SOD (U/mg prot) & $104.57 \pm 1.58^{b}$ & $60.86 \pm 1.72^{\mathrm{a}}$ & $98.88 \pm 2.79^{b}$ & $102.30 \pm 7.69$ \\
\hline & MDA (nmol/ mg prot) & $0.07 \pm 0.01$ & $0.12 \pm 0.02$ & $0.06 \pm 0.04$ & $0.05 \pm 0.01$ \\
\hline \multicolumn{6}{|c|}{ 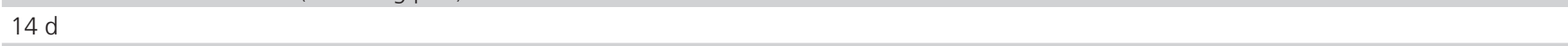 } \\
\hline \multirow{3}{*}{ Serum } & CAT (U/mL) & $18.69 \pm 2.56$ & $15.27 \pm 1.86$ & $18.39 \pm 1.02$ & $18.78 \pm 1.37$ \\
\hline & $\mathrm{SOD}(\mathrm{U} / \mathrm{mL})$ & $145.62 \pm 8.61$ & $130.98 \pm 4.56$ & $141.56 \pm 6.20$ & $151.07 \pm 6.14$ \\
\hline & $\mathrm{MDA}(\mathrm{nmol} / \mathrm{mL})$ & $2.96 \pm 0.29^{a}$ & $4.57 \pm 0.20^{b}$ & $3.11 \pm 0.17^{a}$ & $2.94 \pm 0.32^{\mathrm{a}}$ \\
\hline \multirow{3}{*}{ Jejunum } & CAT (U/mg prot) & $5.60 \pm 1.02$ & $5.05 \pm 0.51$ & $5.78 \pm 1.42$ & $5.83 \pm 1.11$ \\
\hline & SOD (U/mg prot) & $86.53 \pm 2.12^{b}$ & $53.67 \pm 2.19^{a}$ & $82.57 \pm 3.01^{b}$ & $86.49 \pm 4.21^{b}$ \\
\hline & MDA (nmol/ mg prot) & $0.35 \pm 0.10^{a}$ & $0.58 \pm 0.13^{b}$ & $0.42 \pm 0.01^{a}$ & $0.37 \pm 0.06^{a}$ \\
\hline \multirow{3}{*}{ Ileum } & CAT (U/mg prot) & $9.67 \pm 1.13$ & $5.98 \pm 0.52$ & $8.69 \pm 1.23$ & $9.54 \pm 0.75$ \\
\hline & SOD (U/mg prot) & $117.68 \pm 5.07^{b}$ & $66.73 \pm 8.63^{a}$ & $105.91 \pm 2.75^{b}$ & $116.75 \pm 6.38^{b}$ \\
\hline & MDA (nmol/ mg prot) & $0.38 \pm 0.03^{a}$ & $0.59 \pm 0.10 b$ & $0.42 \pm 0.02^{\mathrm{a}}$ & $0.39 \pm 0.03^{a}$ \\
\hline \multicolumn{6}{|l|}{$21 d$} \\
\hline \multirow{3}{*}{ Serum } & CAT (U/mL) & $9.15 \pm 1.36^{b}$ & $4.56 \pm 1.21^{\mathrm{a}}$ & $8.30 \pm 0.62^{b}$ & $9.51 \pm 0.73^{b}$ \\
\hline & $\mathrm{SOD}(\mathrm{U} / \mathrm{mL})$ & $180.68 \pm 6.50^{b}$ & $100.01 \pm 5.59^{a}$ & $175.69 \pm 7.41^{b}$ & $183.46 \pm 7.37^{b}$ \\
\hline & $\mathrm{MDA}(\mathrm{nmol} / \mathrm{mL})$ & $1.83 \pm 0.12^{\mathrm{a}}$ & $3.56 \pm 0.20^{b}$ & $2.14 \pm 0.19^{a}$ & $1.90 \pm 0.11^{\mathrm{a}}$ \\
\hline \multirow{3}{*}{ Jejunum } & CAT (U/mg prot) & $14.58 \pm 1.12^{b}$ & $7.46 \pm 1.95^{a}$ & $13.39 \pm 2.54^{b}$ & $14.49 \pm 1.70^{b}$ \\
\hline & SOD (U/mg prot) & $175.32 \pm 15.39$ & $133.94 \pm 10.27$ & $159.60 \pm 2.49$ & $169.97 \pm 7.83$ \\
\hline & MDA (nmol/ mg prot) & $0.39 \pm 0.01^{a}$ & $0.98 \pm 0.15^{b}$ & $0.49 \pm 009^{a}$ & $0.43 \pm 0.08^{\mathrm{a}}$ \\
\hline \multirow{3}{*}{ Ileum } & CAT (U/mg prot) & $8.89 \pm 1.00$ & $5.62 \pm 0.71$ & $7.76 \pm 1.72$ & $8.65 \pm 2.02$ \\
\hline & SOD (U/mg prot) & $119.86 \pm 15.20^{b}$ & $69.92 \pm 9.12^{\mathrm{a}}$ & $99.96 \pm 11.60^{a}$ & $113.51 \pm 9.18^{a}$ \\
\hline & MDA (nmol/ mg prot) & $0.30 \pm 0.02^{\mathrm{a}}$ & $0.62 \pm 0.12^{b}$ & $0.36 \pm 0.10^{a}$ & $0.30 \pm 0.08^{a}$ \\
\hline
\end{tabular}

${ }^{1} \mathrm{CON}=$ noninfect control group, $\mathrm{SCC}=\mathrm{S}$. Enteritidis infect control group received the basal diet, Gln $1=S$. Enteritidis infect control group received the basal diet plus $0.5 \%$ Gln; $\mathrm{G} \ln 2=S$. Enteritidis infect control group received the basal diet plus $1.0 \% \mathrm{Gln}$.

$2, \mathrm{a}, \mathrm{b}$ Values within the same row that do not share a common superscript are significantly different at $p<0.05 ; \mathrm{n}=8$. 
the $S$. Enteritidis infection group $(p<0.05)$, although there were no differences when compared with the CAT and SOD of the CON group ( $p>0.05)$. S. Enteritidis infection increased the serum MDA in the SCC group at $d 7,14$, and 21 compared with the CON group. However, the GIn 1 and Gln 2 groups showed decreased serum MDA as compared with the $S$. Enteritidis infection group $(p<0.05)$, but the MDA content of GIn groups showed no differences when compared with those of the CON group ( $p>0.05)$. Serum CAT (14d), SOD (d 14), and MDA ( $d$ 4) were not affected after infection, and no significant differences were seen among the treatment groups ( $p>0.05$ ).

S. Enteritidis infection significantly increased the mucosa MDA contents of the jejunum and ileum at $d$ 4, 7 (apart from the ileum), 14, and 21 when compared with the MDA contents of the CON group $(p<0.05)$. Compared with the $S$. Enteritidis-challenged groups, the MDA contents of the jejunum and ileum mucosa in the Gln-treated groups were lower than those of the $S$. Enteritidis infection broilers $(p<0.05)$. There was no difference on the activity of SOD in the intestinal mucosa at $d 4$ and jejunal mucosa at $d 7$ or $21 \mathrm{~d}$ among the three groups $(p>0.05)$. S. Enteritidis infection decreased the SOD activity of the intestinal mucosa at d 14 and the ileal mucosa at d 7, 14, and 21 when compared with the SOD activity of the CON group $(p<0.05)$. However, GIn 1 and Gin 2 groups showed increased SOD activity $(p<0.05)$ when compared with the SOD activity of the $S$. Enteritidis infection group. There was no difference on the activity of CAT in the intestinal mucosa at $d 7$ and 14, and ileal mucosa at d 21 among the three groups ( $p>0.05)$. The CAT activity of the intestinal mucosa at $d 4$ and the jejunal mucosa at $d 14$ and 21 in the SCC group $(p<0.05)$ was less than that of the CON group $(p<0.05)$. However, the GIn 1 and Gln 2 groups showed increased SOD activity $(p<0.05)$ compared with the SCC group.

\section{mRNA expression levels in the intestinal mucosa}

Compared with the CON treatment, the S. Enteritidis infection group showed a significant decrease in the mRNA expression levels of CAT, SOD, and Nrf2 at 4, 7 , and 14 days of age $(p<0.05)$ (Table 6$)$. Compared with the $S$. Enteritidis challenged groups, the mRNA expression levels of CAT, SOD, and Nrf2 in the Gln treatment were higher than those of the $S$. Enteritidis infection group $(p<0.05)$, but there were no differences when compared with the mRNA expression levels of CAT, SOD, and Nrf2 in the CON treatment ( $p>0.05)$.
There were rather large differences in the CAT, SOD, and Nrf2 mRNA expression levels of the ileal mucosa at 21 days of age. Appliances in the SCC group exhibited decreased CAT, and Nrf2 mRNA expression levels in the jejunal and ileal mucosa as compared with the CON group $(p<0.05)$. The Gln treatment group showed upregulated mRNA expression levels of the above-mentioned genes in comparison with the $S$. Enteritidis infection group $(p<0.05)$, but there were no differences when compared with the jejunal and ileal mucosa of the CON group ( $p>0.05$ ). At 21 days of age, there were no differences on the mRNA expression levels of SOD in the jejunal and ileal mucosa among the groups ( $p>0.05)$.

\section{DISCUSSION}

Previous studies have reported that young chickens infected with Salmonella present cachexia, shivering, clustering, head dropping, wing prolapse, loss of appetite, difficulty breathing, loss of body weight, diarrhea, and intestinal lesions from inflammation and damage to villi, leading to high mortality rates (Suzuki, 1994; Ma et al., 2014; Zhou et al., 2014). In our experiment, oral infection with Salmonella was not severe enough to lead to high mortality in the chickens (3.33\%), but it did effectively activate the antioxidant system to protect against infection. Moreover, the results of our experiment study revealed that the infection with $S$. Enteritidis led to a difference in the average body weight between the SCC and CON group at $d 7,14$, and 21 . The results suggest that the infection was successful and are consistent with some published studies (Zhou et al., 2014; Wu et al., 2018) that found that the oral vaccination of $S$. Enteritidis in broilers negatively affected the average body weight. The experimental results on chicken growth performance and mortality in this study were slightly different from the findings of others (Bohez et al., 2008; Haider et al., 2012). These differences between the experimental results are probably due to chick age at the infection, strain variations, challenge dosages, animal management, and environmental conditions (Liu et al., 2018; Wu et al., 2018). However, dietary GIn supplementation showed that the abovementioned clinical symptoms disappeared; the mortality decreased, and the average body weight of the birds under infection conditions improved to levels similar to the healthy broilers.

Our present experiment results indicated that Gln increased the average body weight, which was 
Table 6 - Effect of dietary GIn on the expressioin of genes broilers infected with S. Enteritidis.

\begin{tabular}{|c|c|c|c|c|c|}
\hline \multirow{2}{*}{ Items } & & \multicolumn{4}{|c|}{ Diet Treatments $^{1}$} \\
\hline & & $\mathrm{CON}$ & SCC & $\mathrm{G} \ln 1$ & $\mathrm{G} \ln 2$ \\
\hline \multicolumn{6}{|l|}{$4 d$} \\
\hline \multirow{3}{*}{ Jejunum } & CAT & $0.84 \pm 0.06^{b}$ & $0.61 \pm 0.07^{a}$ & $0.80 \pm 0.03^{b}$ & $0.86 \pm 0.03^{b}$ \\
\hline & SOD & $0.92 \pm 0.12^{b}$ & $0.52 \pm 0.10^{a}$ & $0.87 \pm 0.07^{b}$ & $0.92 \pm 0.04^{b}$ \\
\hline & Nrf2 & $1.15 \pm 0.06^{b}$ & $0.68 \pm 0.09^{a}$ & $1.04 \pm 0.07^{b}$ & $1.15 \pm 0.08^{b}$ \\
\hline \multirow{3}{*}{ Ileum } & CAT & $0.80 \pm 0.08^{b}$ & $0.49 \pm 0.06^{a}$ & $0.78 \pm 0.10^{b}$ & $0.82 \pm 0.04$ \\
\hline & SOD & $0.80 \pm 0.01^{b}$ & $0.44 \pm 0.05^{\mathrm{a}}$ & $0.78 \pm 0.01^{b}$ & $0.81 \pm 0.02^{b}$ \\
\hline & $\mathrm{Nrf2}$ & $1.09 \pm 0.04^{b}$ & $0.62 \pm 0.05^{a}$ & $0.97 \pm 0.09^{b}$ & $1.08 \pm 0.10^{b}$ \\
\hline \multicolumn{6}{|l|}{$7 d$} \\
\hline \multirow{3}{*}{ Jejunum } & CAT & $0.88 \pm 0.03^{b}$ & $0.64 \pm 0.07^{a}$ & $0.84 \pm 0.01^{b}$ & $0.90 \pm 0.02^{b}$ \\
\hline & SOD & $0.96 \pm 0.12^{b}$ & $0.53 \pm 0.10^{a}$ & $0.88 \pm 0.07^{b}$ & $0.94 \pm 0.04^{b}$ \\
\hline & Nrf2 & $1.07 \pm 0.10^{b}$ & $0.60 \pm 0.06^{a}$ & $0.98 \pm 0.07^{b}$ & $1.05 \pm 0.03^{b}$ \\
\hline \multirow{3}{*}{ Ileum } & CAT & $0.86 \pm 0.10^{b}$ & $0.56 \pm 0.08^{a}$ & $0.82 \pm 0.05^{b}$ & $0.88 \pm 0.11^{b}$ \\
\hline & SOD & $0.84 \pm 0.04^{b}$ & $0.49 \pm 0.04^{a}$ & $0.80 \pm 0.01^{b}$ & $0.85 \pm 0.03^{b}$ \\
\hline & Nrf2 & $1.00 \pm 0.06^{b}$ & $0.59 \pm 0.05^{a}$ & $0.91 \pm 0.03^{b}$ & $0.97 \pm 0.04$ \\
\hline \multicolumn{6}{|l|}{$14 d$} \\
\hline \multirow{3}{*}{ Jejunum } & CAT & $1.08 \pm 0.12^{b}$ & $0.72 \pm 0.11^{a}$ & $0.96 \pm 0.08^{b}$ & $1.07 \pm 0.10^{b}$ \\
\hline & SOD & $1.19 \pm 0.10^{b}$ & $0.58 \pm 0.10^{a}$ & $1.05 \pm 0.11^{b}$ & $1.22 \pm 1.00^{b}$ \\
\hline & Nrf2 & $0.95 \pm 0.02^{b}$ & $0.50 \pm 0.04^{a}$ & $0.89 \pm 0.06^{b}$ & $0.96 \pm 0.08^{b}$ \\
\hline \multirow{3}{*}{ Ileum } & CAT & $0.90 \pm 0.07^{b}$ & $0.65 \pm 0.02^{\mathrm{a}}$ & $0.83 \pm 0.04^{b}$ & $0.92 \pm 0.03^{b}$ \\
\hline & SOD & $0.88 \pm 0.04^{b}$ & $0.50 \pm 0.09^{a}$ & $0.82 \pm 0.03^{b}$ & $0.89 \pm 0.01^{b}$ \\
\hline & $\mathrm{Nrf2}$ & $0.92 \pm 0.07^{b}$ & $0.55 \pm 0.04^{a}$ & $0.88 \pm 0.01^{b}$ & $0.92 \pm 0.03^{b}$ \\
\hline \multicolumn{6}{|l|}{$21 \mathrm{~d}$} \\
\hline \multirow{4}{*}{ Jejunum } & CAT & $1.22 \pm 0.15^{b}$ & $0.96 \pm 0.10^{a}$ & $1.22 \pm 0.09^{a}$ & $1.27 \pm 0.11^{\mathrm{a}}$ \\
\hline & SOD & $1.12 \pm 0.11$ & $0.90 \pm 0.09$ & $1.11 \pm 0.12$ & $1.14 \pm 0.10$ \\
\hline & Nrf2 & $0.89 \pm 0.09^{b}$ & $0.52 \pm 0.05^{\mathrm{a}}$ & $0.80 \pm 0.07^{b}$ & $0.88 \pm 0.06^{b}$ \\
\hline & CAT & $0.96 \pm 0.04^{b}$ & $0.70 \pm 0.07^{a}$ & $0.87 \pm 0.06^{b}$ & $0.94 \pm 0.02^{b}$ \\
\hline \multirow[t]{2}{*}{ Ileum } & SOD & $0.93 \pm 0.07$ & $0.91 \pm 0.09$ & $0.93 \pm 0.05$ & $0.95 \pm 0.08$ \\
\hline & $\mathrm{Nrf2}$ & $0.81 \pm 0.03^{b}$ & $0.49 \pm 0.06^{a}$ & $0.75 \pm 0.06^{b}$ & $0.80 \pm 0.04$ \\
\hline
\end{tabular}

${ }^{1} \mathrm{CON}=$ noninfect control group, $\mathrm{SCC}=\mathrm{S}$. Enteritidis infect control group received the basal diet, Gln $1=S$. Enteritidis infect control group received the basal diet plus $0.5 \%$ Gln; $\mathrm{G} \ln 2=S$. Enteritidis infect control group received the basal diet plus $1.0 \% \mathrm{Gln}$.

$2, a, b$ Values within the same row that do not share a common superscript are significantly different at $p<0.05 ; n=8$.

similar to a previous study by Xue et al. (2018). These studies indicated that supplementing the diet with Gln may improve the weight gain of broilers under stress conditions, which may partly depend on the advantageous effect of Gln on the growth and development of the digestive organs (Uni et al., 1999). Some studies reported that GIn could increase the intestinal fold height and number, maintaine the integrity and function of the gut, and reduce the adhesion and invasion of pathogenic bacterial (Dai et al., 2013; Xu et al., 2014). In contrast, it has been reported that diet containing GIn did not improve the average body weight gain of broilers under stress conditions (Shakeri et al., 2016). These different results may be directly related to the proper addition of Gln, the rearing period of the appliances (Shakeri et al., 2016), the levels and sources of stress, etc. Our results also showed that diet GIn enhanced the average body weight associated with antioxidant (CAT and SOD) and digestive enzyme activity.
Digestive enzyme activity is considered to be a reliable indicator of digestive capacity, intestinal development, and the nutritional status of the individual. A variety of factors can affect digestive enzyme activity, including different dietary supplements, the type, and degree of stress, intestinal microflora, degree of intestine development, and feeding conditions (Xue et al., 2018). Previous reports revealed that digestive enzyme activity decreased after Salmonella infection (Zhang et al., 2016; Tang et al., 2018), probably due to its capacity to reduce the populations of beneficial microorganisms and impaired intestinal mucosa and function, which dramatically influences the early intestinal microbial balance and purpose in chickens. Our present study found that GIn supplementation in the S. Enteritidis infected broiler groups promoted the activities of digestive enzyme (trypsin, lipase, and amylase). Similarly, a similar increase in digestive enzyme activity was noted in other animals fed Glnsupplemented feed (Xu et al., 2014). These effects 
were likely due to GIn administration, which interacted with food matrix components and was involved in nutrient metabolism and absorption. Besides, Gln also induced protection of the intestinal mucosal integrity by preventing the bacteria translocation, regulating the balance of intestinal microorganisms and consequently promoting the digestion and absorption of feed nutriment. Finally, the benefit of GIn may be related to the promoted development of the pancreas in broilers to some extent (Pinkus \& Berkositz, 1980). The results of this experiment also showed that the change in the digestive enzyme activity was different with age, which is probably connected with the maturation of the digestive system, causing different $\mathrm{pH}$ values and gut permeability at different ages (Mahagna et al., 1995; Shapiro \& Nir, 1995). However, digestive enzyme activity was higher in the chicken jejunum than in the ileum. These effects might be ultimately connected with the changes in indigestion due to changes in the histological structure of the digestive tract, acidic $\mathrm{pH}$ values, and microbiota composition (Sohail et al., 2012; Wu et al., 2018). The effect of glutamine on the digestive enzyme activity in different parts of the small intestine needs further study.

Stress can disrupt cellular homeostasis, thereby inducing the excessive production or accumulation of reactive oxygen species (ROS) or lipid peroxides, causing oxidative injury in animals (Liu et al., 2015). Some studies have shown that oxidative stress of the intestine and substantially reconstructed mucosal barriers occur in S. Enteritidis -challenged birds (Wu et al., 2018). Our present study showed that S. Enteritidis infection led to reduced plasma and intestinal mucosa SOD and CAT activity. Elevated plasma and intestinal mucosa MDA concentrations in the $S$. Enteritidis infected treatment, caused intestinal mucosal barriers and caused the body to experience an unbalanced oxidant/antioxidant status in Salmonella-challenged broilers, compared with the CON treatment group. These results are in agreement to previous findings that suggested increased concentrations of MDA detected in bacteria-infected chickens (Wu et al., 2018).

However, the administration of Gln to infected animals can eliminate ROS, such as superoxide dismutase, hydrogen peroxide, and hydroxyl radicals, to reduce oxidant lesions, which may be associated with the reactive oxygen-derived free radical ability (Chen et al., 2009; Hu et al., 2014). Dietary supplementation with GIn decreased MDA concentrations and increased the SOD and CAT activities in S. Enteritidis-infected broilers in the present study. The current results are consistent with the published reports (Brasse-Lagnel et al., 2009; Liu et al., 2015), which revealed that the Gln attenuated oxidative damage to the intestines and body. Also, the detection of molecular stress biomarkers indicated that the administration of Gln mediated the expression of genes associated with antioxidant activity (CAT, SOD, and Nrf2). These results suggest that dietary Gln scavenges free radicals and increases antioxidation, likely through the mediation of reactions that reduce oxidized protein levels and normalize index enzyme activities, which may consequently attenuate renal oxidative damage in Enteritidis-infected broilers, in the intestinal mucosa and sera of ovens (Fathi et al., 2014).

Moreover, Gln is a beneficial precursor for glutathione production in the plasma and intestinal mucosa (Cheng et al., 2011). Therefore, the upregulation of the intestinal antioxidant genes expression levels can also be explained by the use of GIn on the antioxidant enzymes activation of the intestinal mucosa. However, further studies will be needed to clarify the detailed antioxidant mechanism of Gln using genetic manipulation technologies.

\section{CONCLUSION}

Overall, our results indicated that the administration of Gln generally improved the physiological status, growth performance, and the activity of digestive enzyme in broiler chicks. It promoted the antioxidative stability and stress resistance capacities of infected broilers by modulating both actions and the mRNA expression of antioxidant enzymes and decreased MDA, which protect the intestinal mucosa from oxidative damage. It is evident that positively enhanced digestive enzymes and antioxidant activities partly contributed to the beneficial effect of dietary Gln on the average body weight of broilers.

\section{ACKNOWLEDGEMENTS}

This research was supported by a project supported by the National Natural Science Foundation of China (Grant No. 31601971). The authors express special thanks to Qianqian Wang, Xiuqing Zhou, Yazhe Song, and Jing Zhou for skillful technical assistance with this research.

\section{REFERENCES}

Alaeldein MA, Abdullah HA, Yousif MD, Rifat UK. Effect of organic acid blend and Bacillus subtilis alone or in combination on growth traits, blood biochemical and antioxidant status in broilers exposed to Salmonella typhimurium challenge during the starter phase. Journal of Applied Animal Research 2017;45(1):538-542. 
Bohez L, Dewulf J, Ducatelle R, Pasmans R, Haesebrouck F, Van Immersee $F$. The effect of oral administration of a homologous hilA mutant strain on the long-term colonization and transmission of Salmoella Enteritides in broiler chickens. Vaccine 2008;26:372-378.

Bradford MM. A rapid and sensitive method for the quantitation of microgram quantities of protein utilizing the principle of protein-dye binding. Analytical Biochemistry 1976;72: 248-254.

Brasse-Lagner C, Lavoinne A, Husson A. Control of mammalian gene expression by amino acids, especially glutamine. Febs Journal 2009;276:1826-1844.

Castiglioni ENT, Kaneshiro AMI, Stoppa GFZ, Luciano RL, Castro AGM, et al. Important aspects of salmonella in the poultry industry and in public health. In: Mahmoud B, editor. Salmonella: a dangerous foodborne pathogen. London: IntechOpen; 2012.

Chen J, Zhou XQ, Feng L, Liu Y, Jiang J. Effects of glutamine on hydrogen peroxide-induced oxidative damage in intestinal epithelial cells of Jian carp (Cyprinus carpio var. Jian). Aquaculture 2009;288:285-289.

Cheng ZY, Buentello A, Gatlin DM. Effects of dietary arginine and glutamine on growth performance, immune responses and intestinal structure of red drum, Sciaenops ocellatus. Aquaculture 2011;319:247-252.

Dai ZL, Li XL, Xi PB, Zhang J, Wu G, Zhu WY. L-glutamine regulates amino acid utilization by intestinal bacteria. Amino Acids 2013;45:501-512.

Duan YF, Zhang JS, Huang JH, Jiang SG. Effects of dietary Clostridium butyricum on the growth, digestive enzyme activity, antioxidant capacity, and resistance to nitrite stress of Penaeus monodon. Probiotics and Antimicrobial Proteins 2019;11(3):938-945

Fathi M, Tanha T, Daneshyar M. Effects of Glutamine supplementation on Growth performance and antioxidant status in broilers with pulmonary hypertension syndrome (PHS). Iranian Journal of Applied Animal Science 2014;4(3):579-585.

Geng GQ. Pre-treatment with glutamine attenuates lung injury in rats subjected to intestinal ischaemia-reperfusion. Injury 2011;42(1):72-77.

Haider MG, Chowdhury EH, Ahmed AKM, Hossain MM. Experimental pathogenesis of pullorum disease in chicks by local isolate of Salmonella Pullorum in Bangladesh. Journal of the Bangladesh Agricultural University 2012;10(1):87-94

Hu K, Feng L, Jiang W, Liu Y, Jiang J, Li S, et al. Oxidative damage repair by glutamine in fish enterocytes. Fish Physiology and Biochemistry 2014;40:1437-1445

Jacobs DO, Evans DA, Mealy K, Dwyer STO. Combined effects of glutamine and epidermal growth factor on rat intestine. Surgery 1988;104(2):358364.

Kazantzidou D, Tsalis K, Vasiliadis K, Kaldrymidou H, Papageorgiou G, Koliakou K, et al. Alanine-glutamine dipeptide pretreatment protects rat renal function from small intestine ischemia-reperfusion injury. Minerva Chirurgica 2010;65(5):515-525.

Li Y, Wu XB, Li JG, Lin YJ, Chen HL, Liu ZH, et al. Enteral supplementation of alanyl-glutamine attenuates the up-regulation of beta-defensin-2 protein in lung injury induced by intestinal ischemia reperfusion in rats. International Journal of Surgery 2014;12(11):1181-1186.

Lin $Y$, Zhou XQ. Dietary glutamine supplementation improves structure and function of intestine of juvenile Jiancarp (Cyprinus carpio Var. Jiam). Aquaculture 2006;256:389-339.

Liu JW, Mai KS, Xu W, Zhang YJ, Zhou HH, Ai QH. Effects of dietary glutamine on survival, growth performance, activities of digestive enzyme, antioxidant status and hypoxia stress resistance of half-smooth tongue sole (Cynoglossus semilaevis Günther) post larvae. Aquaculture 2015;446:48-56.

Liu N, Deng X, Liang C, Cai H. Effect of Broccoli Residues Fermented with Probiotics on the Growth Performance and Health Status of Broilers Challenged with Clostridium Perfringens. Brazilian Journal of Poultry Science 2018;20(4):625-631.

Liu, N, Ru, YJ, Wang, JP, Xu, TS. Effect of dietary sodium phytate and microbial phytase on the lipase activity and lipid metabolism of broiler chickens. British Journal of Nutrition 2010;103(6):862-868.

Livak KJ, Schmittgen TD. Analysis of relative gene expression data using realtime quantitative PCR and the $2^{-\Delta \Delta c t}$ method. Methods 2001;25:402408 .

Ma T, Chang GB, Chen R, Sheng ZW, Dai AQ, Zhai F, et al. Identification of key genes in the gesponse to Salmonella enterica Enteritidis, Salmonella enterica Pullorum, and Poly(I:C) in Chicken Spleen and Caecum. Biomed Research International 2014;154946:1-14.

Mahagna M, Nir I, Larbier M, Nitsan Z. Effect of age and exogenous amylase and protease on development of the digestive tract, pancreatic enzyme activities and digestibility of nutrients in young meat-type chicks. Reproduction Nutrition Development 1995;35(2):201-212.

Newsholme P. Why is L-glutamine metabolism important to cells of the immune system in health, postinjury, surgery or infection. Journal of Nutrition 2001:131:2515-2252.

NRC - National Research Council. Nutrient requirements of poultry. $9^{\text {th }}$ ed Washington: National Academy of Sciences; 1994.

Pinkus LM, Berkositz JM. Utilization of glutamine by canine pancreas in vivo and acinar cells in vitro. Federation Proceedings 1980;39:1902 1903.

Popkova NI, Kernitskii BS, Sorochinskaya EP, Yurkiv VA, Kucherenko NE, Gerasimov AM. Early effects of salmonella endotoxin on the antioxidant enzyme system of the rat liver and intestine. Bulletin of Experimental Biology and Medicine 1984;98(5):1468-1470.

Shakeri M, Zulkifli I, Oskoueian E, Shakeri M, Oskoueian A, Ebrahimi M. Response to Dietary Supplementation of Glutamine in Broiler Chickens Subjected to Transportation Stress. The Journal of the Faculty of Veterinary Medicine, University of Istanbul 2016;42(2):122-131.

Shapiro F, Nir I. Effect of age and exogenous amylase and protease on performance, development of the digestive tract, digestive enzyme activity, and apparent digestibility. Poultry Science 1995;74(12):20192028

Suzuki S. Pathogenicity of Salmonella enteritidis in poultry. International Journal of Food Microbiology 1994;21(1-2):89-105.

Tang XM, Liu YJ, Wu XY, Cheng F, Hu J, Meng XJ, et al. Response of Antioxidant Enzymes and Digestive Enzymes to Temperature Stress in Lates Calcarifer Larvae. Israeli Journal of Aquaculture Bamidgeh 2018;1537(30):1-30

Taunay AE, Fernandes SA, Tavechio AT, Neves BC, Dias AMG., Irino K. The role of Public Health Laboratory in the problem of salmonellosis in Sao Paulo. Revista do Instituto de Medicina Tropical de Sao Paulo 1996:38(2):119-127.

Uni Z, Noy Y, Sklan D. Posthatch development of small intestinal function in the poultry. Poultry Science 1999;78:215-222.

Wu HQ, Ye LL, Lu XX, Xie S, Yang Q, Yu QH. Lacidophilus Alleviated Salmonella-Induced Goblet Cells Loss and Colitis by Notch Pathway. Molecular Nutrition \& Food Research 2018;62(22):e1800552. 
Wu QJ, Jiao C, Liu ZH, Li SW, Zhu DD, Ma WF, et al. Effect of glutamine on the intestinal function and health of broilers challenged with Salmonella pullorum. Indian Journal of Animal Research 2019;53(9):1210-1216.

Wu QJ, Zheng XC, Wang T, Zhang TY. Effect of dietary oridonin supplementation on growth performance, gut health, and immune response of broilers infected with Salmonella pullorum. Irish Veterinary Journal 2018;71:16-21.

Xue GD, Barekatain R, Wu SB, Choct M, Swick RA. Dietary L-glutamine supplementation improves growth performance, gut morphology, and serum biochemical indices of broiler chickens during necrotic enteritis challenge. Poultry Science 2018;97(4):1334-1341.
Zhang $L$, Zhang $L L$, Zhan XA, Zeng XF, Zhou L, Cao GT, et al. Effects of dietary supplementation of probiotic, Clostridium butyricum, on growth performance, immune response, intestinal barrier function, and digestive enzyme activity in broiler chickens challenged with Escherichia coli $\mathrm{K}_{88}$. Journal of Animal Science Biotechnology 2016;(7):3-11.

Zhou G, Wang JG, Zhu XQ, Wu YF, Gao MM, Shen H. Induction of maggot antimicrobial peptides and treatment effect in Salmonella pulloruminfected chickens. Journal of Applied Poultry Research 2014;23(3):376383. 